\title{
Pengenalan Budaya Melalui Bercerita untuk Anak Usia Dini
}

\author{
Yulfrida Rahmawati
}

pedagogiayk@gmail.com

KB \& TK Pedagogia Laboratori FIP UNY

\begin{abstract}
Abstrak
Bangsa yang besar adalah bangsa yang berbudaya dan berkarakter. Kebudayaan mencerminkan karakter sebuah bangsa. Anak-anak yang tumbuh dan berkembang dalam lingkungan budaya tertentu akan membentuk budaya yang mempengaruhi pertumbuhan dan perkembangan. Kebudayaan juga menentukan pola pandang manusia. Inilah yang menjadikan asumsi bahwa budaya sebagai aspek penting dalam pembelajaran anak usia dini. Salah satu cara terbaik mengenalkan budaya adalah melalui mendongeng.
\end{abstract}

Kata kunci: Kebudayaan, Mendongeng, Anak Usia Dini

\begin{abstract}
Great nation is a cultured nation and character. Culture also reflects the character of a nation. Children who grow and develop in a particular cultural environment will bring and cultural factors that affect the growth and development. Culture also determines the pattern of view were a man. This is what makes culture as an important aspect of early childhood learning. One of the best ways through storytelling.
\end{abstract}

Keywords: culture, storytelling, early childhood.

\section{Pendahuluan}

Masih ingatkah dongeng dari nenek kita waktu kecil yang mengatakan bahwa waktu menjelang magrib adalah saat sang Bathara Kala keluar dari persembunyiannya dengan membawa serta anak-anak yang keluar rumah untuk dimangsanya. Ada banyak lagi dongeng-dongeng semacam itu yang sering disampaikan ketika menjelang tidur. Apa yang dilakukan oleh nenek moyang kita tersebut merupakan sebagian dari budaya yang ada di lingkungan masyarakatJ awa.
Tentunya hal tersebut tidak benar-benar terjadi atau cerita karangan belaka yang diceritakan turun-temurun dari nenek moyang pendahulu kita sebagai kiasan dari nasehat yang hendak disampaikan. Mereka sadar bahwa bila nasehat disampaikan secara langsung, penyampaian pesan tidak akan efektif. Sehingga mereka berstrategi menyampaikan pesan tersebut melalui cerita atau dongeng sebelum tidur yang tentunya membuat anakanak akan merasa lebih terkesan dan 
menangkap pesan yang terkandung dalam cerita tersebut.

Dongeng di atas sebenarnya mempunyai maksud atau mengandung nasehat bahwa pada waktu menjelang magrib merupakan saat pergantian waktu dari sore hari yang terang benderang ke waktu malam di mana suasana menjadi gelap gulita sehingga dimungkinkan akan terjadi beberapa hal seperti perubahan cuaca dari panas ke dingin, perubahan suasana dari terang ke gelap, dan memungkinkan pula pada saat tersebut adalah saat keluarnya binatang-binatang malam. Tentunya merupakan kondisi yang kurang baik bagi seseorang apalagi anak kecil untuk berada di suasana yang demikian. Dengan demikian, bercerita merupakan strategi yang efektif untuk menyampaikan nasehat kepada kepada anak-anak.

Bangsa yang unggul adalah bangsa yang berbudaya dan berkarakter. Anak yang tumbuh dan berkembang dalam suatu lingkungan budaya tertentu akan membawa serta budaya yang mempengaruhi proses tumbuh dan berkembangnya. Hal tersebut yang menjadikan budaya sebagai aspek penting dalam proses pembelajaran anak usia dini. Salah satunya ialah kegiatan bercerita.

\section{Pengertian Anak Usia Dini}

Menurut UU No. 20 Tahun 2003

Tentang Sistem Pendidikan Nasional Pasal 1 butir 14, "Pendidikan anak usia dini adalah suatu upaya pembinaan yang ditujukan kepada anak sejak lahir sampai dengan usia enam tahun yang dilakukan melalui pemberian rangsangan pendidikan untuk membantu pertumbuhan dan perkembangan jasmani dan rohani agar anak memiliki kesiapan dalam memasuki pendidikan lebih lanjut".

Selain itu, menurut NAEYC (National Association for The Education Young Children) bahwa anak usia dini adalah anak yang berumur nol tahun hingga berusia kurang lebih delapan tahun (Santoso dalam Musfiroh, 2005). Masa usia dini merupakan periode emas (golden age) bagi perkembangan anak untuk memperoleh proses pendidikan. Periode ini adalah tahun-tahun berharga bagi seorang anak untuk mengenali berbagai macam fakta di lingkunganya sebagai stimulan bagi perkembangan kepribadian, psikomotor, kognitif, bahasa, dan sosialnya.

Anak usia dini meniru apa yang ia lihat, rasakan dan dengar dari lingkungannya. Hal tersebut karena ia belum mengetahui batasan benar atau salah, baik atau buruk serta pantas atau tidak pantas. Oleh karena itu, masa ini adalah masa yang peka terhadap pengaruh dari lingkungan dan merupakan kesempatan bagi lingkungan yang dalam hal ini ialah orang tua dan guru untuk memberikan pengaruh yang mendidik seluasluasnya kepada anak untuk membantu mengembangkan perilaku anak yang positif.

\section{Pentingnya Bercerita untuk Anak Usia Dini}

Cerita dapat digunakan oleh orang tua dan guru sebagai sarana mendidik dan membentuk kepribadian anak melalui pendekatan transmisi budaya atau cultural transmission approach (Suyanto \& Abbas dalam Musfiroh, 2005)

Bercerita adalah suatu kegiatan yang dilakukan seseorang untuk menyampaikan suatu pesan atau informasi atau pun dongeng belaka yang bisa dilakukan secara lisan maupun tertulis. Cara penyampaian cerita tersebut dapat dilakukan dengan menggunakan alat peraga atau tanpa alat peraga. Cerita yang menarik bagi anak tentunya adalah cerita yang bersumber dari pengalaman seharihari yang mungkin dialami ataupun hal-hal sederhana yang mudah dicerna anak. Cara penuturan pun harus 
menarik sehingga perhatian anak akan terfokus pada tuturan cerita yang kita sampaikan. Bercerita juga dapat membantu perkembangan imajinasi anak. Dalam bercerita anak akan belajar tentang bahasa dan mengenal berbagai emosi dan perasaan. Bercerita juga merupakan sarana efektif untuk mengenalkan nilai-nilai budaya kepada anak.

Menurut Gunarti, Suryani \& Muis (2008), tujuan yang ingin dicapai dalam kegiatan bercerita adalah :

1. Mengembangkan kemampuan berbahasa, diantaranya kemampuan menyimak (listening), juga kemampuan dalam berbicara (speaking) serta menambah kosakata yang dimilikinya.

2. Mengembangkan kemampuan berpikirnya karena dengan bercerita anak diajak untuk memfokuskan perhatian dan ber-fantasi mengenai jalan cerita serta mengembangkan kemampuan berpikir secara simbolik.

3. Menanamkan pesan-pesan moral yang terkandung dalam cerita yang akan mengembangkan kemampuan moral dan agama.

4. Mengembangkan kepekaan sosial-emosional anak tentang halhal yang terjadi di sekitarnya melalui cerita yang disampaikan.

5. Mengembangkan potensi kreatif anak melalui keragaman ide cerita yang disampaikan.

Cerita bagi anak usia dini sebaiknya menyenangkan dan bermanfaat. Menyenangkan karena bersumber dari pengalaman hidup manusia. Sedangkan bermanfaat karena dalam cerita banyak terkandung nilai-nilai kehidupan yang dapat dicerna oleh siapapun juga termasuk anak-anak. Cerita digolongkan sebagai cerita yang baik apabila memiliki alur cerita yang baik pada awal, tengah, maupun akhir cerita. Selain itu perlu plot cerita, karakter tokoh, kata-kata imajinatif, humor atau drama yang dapat mem- bangkitkan emosi dan imajinasi anak. Bahasa juga diolah sebaik-baiknya untuk memaparkan cerita sehingga lebih menarik.

Menurut Musfiroh (2005), halhal yang perlu diperhatikan dalam pemilihan cerita untuk anak adalah tema, pesan, tokoh, alur cerita, dan latar.

a. Tema

Tema adalah makna yang terkandung dalam cerita yang merupakan gagasan atau ide yang mendasari suatu cerita (Sudjiman dalam Musfiroh, 2005). Untuk cerita-cerita tradisional biasanya tema yang digunakan berkaitan dengan kebaikan dan kejahatan serta biasanya bersifat turuntemurun. Tema cerita bagi anak sebaiknya disesuaikan dengan dunia anak dan sebaiknya dipilih cerita bertema sosial maupun ketuhanan.

Tema yang dapat dipilih misalnya: tema kemanusiaan ( tentang tolong-menolong, kejujuran, persahabatan, dan lain-lain.), tema binatang (kancil, buaya, kelinci, monyet) dan sebaiknya memilih tema yang tradisional yaitu tema yang berbicara mengenai baik-buruk atau benar-jahat. Tema tradisional ini sangat penting karena mampu berperan dalam pembentukan pribadi anak untuk mencintai kebenaran dan menentang kejahatan.

b. Amanat

Amanat adalah cerminan pandangan hidup pengarang tentang nilai-nilai kebenaran yang ingin disampaikan kepada pembacanya maupun pendengarnya. Pesan disampaikan secara implisit maupun eksplisit. Kadang anak dapat segera menangkap isi dari cerita yang disampaikan guru tapi kadang guru pun sebaiknya menegaskan pesan lewat pertanyaan-pertanyaan pada pertengahan cerita maupun akhir 
cerita dan lewat kesimpulan yang akan disampaikan pada saat akhir cerita.

Amanat bersifat tak terbatas yang dapat mencakup semua persoalan hidup dan kehidupan. Dalam hal ini persoalan hidup manusia dapat dipilah dari bentuk hubungannya yaitu hubungan antara manusia dengan manusia, hubungan antara manusia dengan Tuhan, dan hubungan manusia dengan dirinya sendiri. Amanat cerita untuk anak berbeda dengan pesan cerita untuk anak. Untuk cerita orang dewasa kadang pesan yang disampaikan menjadi tidak jelas karena olah bahasa sastra dan pembaca diharap dapat menyimpulkan isi cerita sendiri sesuai dengan interpretasi masing-masing pembacanya. Sedangkan untuk cerita anak jelas harus ada pesan eksplisit yang akan disampaikan. Hal ini terkait karena anak baru bisa berpikir konkrit dan belum bisa berpikir abstrak.

Amanat dalam cerita menjadi sangat penting karena merupakan maksud dari cerita yang akan disampaikan kepada pembacanya. Amanat sebenarnya merupakan gagasan yang mendasari suatu cerita yang akan disampaikan. Amanat yang akan disampaikan lewat cerita tentunya akan berbeda dengan pesan yang akan disampaikan secara langsung.

c. Tokoh

Tokoh adalah individu rekaan yang mengalami berbagai peristiwa dalam cerita. Tokoh pada cerita untuk anak usia dini bisa berwujud manusia, binatang, maupun benda-benda. Tokoh binatang maupun benda dalam cerita dapat bertingkah seperti manusia (Sudjiman dalam Musfiroh, 2005). Tokoh cerita biasanya adalah rekaan tetapi tetap mencerminkan sifat atau perilaku manusia dalam dunia nyata. Tokoh cerita biasanya juga adalah tokoh-tokoh yang dekat dengan dunia anak, misalnya: tokoh baik dan tokoh buruk. Tokoh cerita anak usia dini akan berbeda dengan tokoh cerita orang dewasa, karena tokoh untuk cerita anak usia dini sebaiknya memilih karakter yang sederhana dan mudah diingat oleh anak. Misalnya tokoh binatang maupun pahlawan pembela kebenaran.

d. Alur cerita

Menurut Musfiroh (2005), alur cerita adalah peristiwa-peristiwa naratif yang disusun dalam serangkaian waktu. Peristiwa-peristiwa tersebut saling berhubungan dengan alur yang sederhana dan merupakan hubungan sebab akibat.

Hal tersebut sesuai dengan prinsip bahwa anak usia dini masih berpikir secara konkrit dan sederhana sehingga informasi lebih mengena disampaikan lewat cerita tentunya dengan alur yang sederhana dan tidak rumit.

Seperti biasa dalam sebuah karangan cerita terdiri dari tiga bagian, yaitu: pembukaan, inti, dan penutup. Pembukaan dalam sebuah cerita mengandung awal masalah yang dilanjutkan dengan klimak dan penyelesaian masalah yang terdapat dalam inti cerita. Penutup cerita biasanya merupakan kesimpulan cerita atau mengandung pesan-pesan yang ingin disampaikan oleh pengarang atau penutur cerita.

e. Latar

Menurut Musfiroh (2005), latar adalah unsur cerita yang menunjukkan kepada penikmatnya di mana dan kapan cerita berlangsung. Namun untuk cerita anak usia dini biasanya latar tidak terlalu dikupas secara tuntas atau hanya menampilkan gambarangambaran secara umum saja, 
misalnya, dahulu kala di hutan rimba, pada suatu saat di sebuah negeri dongeng, dsb.

\section{Pengertian Budaya}

Menurut Koentjaraningrat, kebudayaan dengan kata dasar budaya berasal dari bahasa sansekerta "buddhayah", yaitu bentuk jamak dari buddhi yang berarti "budi" atau "akal". J adi, Koentjaraningrat mendefinisikan budaya sebagai "daya budi" yang berupa cipta, karsa dan rasa, sedangkan kebudayaan adalah hasil dari cipta, karsa dan rasa itu. Kebudayaan adalah keseluruhan sistem gagasan, tindakan, dan hasil karya manusia dalam rangka kehidupan masyarakat yang dijadikan milik diri manusia dengan belajar.

Ki Hajar Dewantara berpendapat bahwa kebudayaan berarti buah budi manusia sebagai hasil perjuangan manusia terhadap dua pengaruh kuat, yakni zaman dan alam yang merupakan bukti kejayaan hidup manusia untuk mengatasi berbagai rintangan dan kesukaran didalam hidup dan penghidupannya guna mencapai keselamatan dan kebahagiaan yang pada lahirnya bersifat tertib dan damai. Budaya adalah suatu cara hidup yang berkembang dan dimiliki bersama oleh sebuah kelompok orang dan diwariskan dari generasi ke generasi. Budaya menjadi penuntun kehidupan masyarakat yang meyakininya karena budaya meliputi banyak hal, baik tata sikap perilaku, agama, berbahasa, berpakaian, dan sebagainya.

\section{Pengenalan Budaya untuk Anak Usia Dini}

Anak belajar tentang normanorma dan nilai-nilai dari lingkungan mereka. Mereka belajar melalui apa yang mereka lihat, dengar dan rasakan. Sehingga contoh langsung akan lebih berkesan bagi anak dalam menanamkan nilai budaya kepada mereka. Terlihat dari perilaku anak yang tinggal di daerah Yogyakarta dengan anak yang tinggal di daerah lain tentu akan berbeda karakter bahasa maupun perilaku mereka. Melalui cerita, pengenalan tentang budaya akan lebih berkesan. Banyak cerita yang biasanya dituturkan oleh orang tua kita terutama ketika menjelang tidur, dengan harapan pada saat tersebut biasanya anak akan lebih rileks sehingga akan lebih berkesan tentang maksud cerita yang disampaikan. Cerita juga dapat disampaikan di luar rumah atau di alam terbuka dengan tetap memperhatikan segi kenyamanan anak.

Penyampaian cerita bisa dilakukan dengan cara langsung maupun menggunakan alat peraga yang relevan dengan cerita yang hendak disampaikan. Alat peraga yang digunakan bisa alat langsung maupun alat simbolik. Sedangkan untuk menyampaian cerita secara langsung jelas memerlukan teknik atau kemampuan lebih dari penuturnya, baik dari segi olah gerak, olah bahasa atau suara maupun mimik atau ekspresi wajah sebagai pencerminan dari cerita yang disampaikan.

Beberapa cerita rakyat cenderung dipilih oleh orang tua karena mereka tinggal menuturkannya tanpa mengarangnya terlebih dahulu tentunya akan disampaikan dengan improvisasi yang berbeda-beda oleh masing-masing penutur cerita. Namun pemilihan cerita yang hendak disampaikan pun perlu lebih selektif dikarenakan kadang justru menimbulkan imajinasi yang berlebihan pada diri anak.

Cerita yang sering disampaikan orang tua kepada anak mereka adalah Timun Emas, Bawang Putih dan Bawang Merah, si Kancil, J aka Kendil, dan sebagainya. Selain itu ada juga cerita yang bersifat kepahlawanan seperti Pangeran Diponegoro, J enderal Sudirman, serangan Umum Satu Maret, J aka Tingkir, Wali Sanga, dan lain-lain. Cerita tentang perilaku sehari-hari, misalnya menanam padi atau "tandur", hajatan, selapanan, dan 
lain-lain. Namun tidak ada salahnya orang tua juga mengenalkan cerita tokoh pewayangan yang tentunya sarat dengan nilai-nilai budaya.

Penyampaian cerita juga dapat dilakukan melalui teknik wayang kancil. Adapun bahan dan alat yang perlu disiapkan antara lain kertas karton atau kertas bekas yang tebal, contoh gambar binatang, spidol, gunting, tali, dan bilah bambu sebagai pegangan.

Langkah-langkah:

a. Orang tua menyiapkan materi cerita yang akan disampaikan

b. Orang tua membuat wayang kancil yang biasanya tokoh-tokohnya adalah binatang menggunakan kertas karton yang telah dipola dan dipasang bilah bambu sebagai pegangannya.

c. Pemilihan tempat yang nyaman

d. Pengkondisian anak termasuk pijakan tentang aturan mendengarkan cerita

e. Pementasan wayang kancil

f. Diakhiri dengan evaluasi yang meliputi tanya jawab tentang isi cerita, tokoh yang dapat ditiru anak maupun tokoh yang tidak boleh ditiru.

Anak juga dapat dilibatkan langsung dalam hal ini pada saat proses pembuatan alat peraga dan pemilihan lokasi atau tempat untuk penyampaian cerita. Pada saat cerita telah selesai, anak dapat berkesempatan untuk memilih tokoh wayang yang disukainya untuk dapat digunakan sebagai mainan.

Cara yang lain adalah dengan alat peraga berupa peralatan dapur, seperti : siwur, enthong, serok, wajan, anglo, tambir, tampah, cowek, dsb, yang digunakan sebagai alat peraga dalam cerita fungsi-fungsi peralatanm dapur tradisional. Tentunya anak nantinya akan diperkenankan untuk mencoba sendiri berimprovisasi dengan alat-alat dapur tersebut sehingga anak akan lebih menyenangkan dan berkesan bagi anak.

\section{Penutup}

Pengenalan budaya khususnya kepada anak usia dini akan lebih bermakna apabila dilakukan dengan teknik atau cara yang benar. Cara tersebut salah satunya adalah dengan bercerita, dimana anak akan lebih terkesan dengan bahasa-bahasa anak, alat peraga yang menarik dan anak dilibatkan langsung baik untuk proses penyiapannya maupun proses penyampaian ceritanya.

Pengenalan budaya lokal akan lebih bermakna dan menarik tentunya dengan cara mendengarkan cerita. Dengan proses pengembangan imajinasinya anak diharapkan dapat berubah pola pikir sesuai dengan nilainilai budaya yang ingin disampaikan.

\section{Daftar Pustaka}

Abdul Majid, DR. Abdul Aziz. Mendidik Dengan Cerita. Rosda.

Asri Budiningsih, C. 2006. Strategi Pembelajaran. Yogyakarta : Fakultas Ilmu Pendidikan Universitas Negeri Yogyakarta.

Gunarti, Winda, Suryani, Lilis \& Muis, Azizah. 2008. Metode Pengembangan Perilaku Dan Kemampuan Dasar Anak Usia Dini. Jakarta : Universitas Terbuka.

Itadz, Mbak. 2008. Memilih, Menyusun, dan Menyajikan Cerita Untuk Anak Usia Dini. Yogyakarta : Tiara Wacana.

Kusuma, Afandi. 2009. "Definisi Kebudayaan Menurut Para Ahli". Diakses dari http://afand.abatasa.com/post/k 
ategori/1104/sosial pada 10 mei 2012.

Musfiroh, Tadkiroatun. 2005. Bercerita Untuk Anak Usia Dini. J akarta : Departemen Pendidikan Nasional Direktorat J enderal Pendidikan Tinggi Direktorat Pembinaan pendidikan Tenaga Kependidikan Dan Ketenagaan Perguruan Tinggi. 